\title{
The Miniature of Siparti 3-S: KSM Sibermas in the Urban Poverty Project in Kelurahan Tlogomas, Kecamatan Lowokwaru, Malang, Indonesia
}

\author{
Mit Witjaksono \\ Faculty of Economics, State University of Malang (UM), Indonesia
}

\begin{abstract}
The miniature presented here is the synthesis of how the Siparti 3-S as an approach and practice in dealing with the community empowerment under the UPP (Urban Poverty Project) in Indonesia. The notion of Siparti 3-S as an approach was applied specifically to build and operate a KSM in a kelurahan area in the year of $2000-2001$ of UPP1 second phase. The practice of how Siparti 3-S applied through the KSM Sibermas project was inspired and motivated by the previous successful of the author's project in executing a training program for the retrenched tertiary graduates who had lost their jobs due to the financial crisis during 1998, under the project was known as P3T Proyek Penanggulangan Pengangguran Pekerja Terampil (Skilled Workers Unemployment Project). Utilization of waste materials to produce sound economic and environmental-friendly products was the theme of project run by KSM Sibermas. Based on the field experience of the author and members of KSM Sibermas in accomplishing the project, found that the Siparti 3-S was effective in building synergistically the three main resources, namely: human (the training participants), nature \& environment (waste materials \& garbage dump), and social-culture (the mindset and the behavior toward handling waste materials).
\end{abstract}

Keywords: Siparti 3-S, KSM Sibermas, Urban Poverty Project, Indonesia

\section{The Urban Poverty Project (UPP) in Indonesia}

INTRODUCTION

The Urban Poverty Project (UPP), or Proyek Penanggulangan Kemiskinan di Perkotaan (P2KP) was one of of the largest poverty alleviation program in Indonesia. It was funded from a World Bank loan of US\$100 million, with counterpart financing of US\$10 million from the Indonesian government. The first such project (UPP1) became effective in 1999 and closed in 2004. The second operation (UPP2) became effective in 2002 and closed in 2010. A third project (UPP3) was approved in 2005, and was implemented in parallel to this project, closing in 2011.

The descriptions of UPP1 (first and second phases) below are summarized from the Project Appraisal Document (PAD) published by the World Bank (Jakarta, April 19, 2009; esp. Annex 2, pp. 17-33). 
The objectives of UPP1 are to:

1. fund activities to benefit the poor in kelurahan on an ongoing basis via (a) capital to revolve for sustainable income generation, and (b) grants for basic infrastructure works and related employment;

2. empower urban communities to help them overcome poverty, and

3. Improve capability of local agencies to assist poor communities.

The first phase project will begin in 59 districts of Java, in the northern half and in Yogyakarta, Bandung and Malang, where most of the dense urban areas and urban poor are located. They comprise 1305 kelurahans with more than 7500 persons each and total some 23 million people and 1540 smaller kelurahan, totaling some Rp7 million. Bappedas I and II have ranked kelurahans in the 59 districts. "Southern" Java comprises 1,360 kelurahan, of which 1,052 are small. Coverage of a second phase will be determined about mid 1999, and depends partly on the rupiah exchange rate that determines the loan funding reach. Camats are to pinpoint the poorer RWs (each kelurahan averages 10 RW, each RW averages 500 families) based on income levels and other household poverty criteria.

Funding allocations are grants to kelurahans varying according to size as the following table (page 18).

\begin{tabular}{|c|c|c|c|c|c|}
\hline & Very Small & Small & Medium & Large & Very Large \\
\hline 1995, Population, Persons & $<7,500$ & $\begin{array}{l}7,500- \\
15,000\end{array}$ & $\begin{array}{l}15,001- \\
22,500\end{array}$ & $\begin{array}{l}22,501- \\
30,000\end{array}$ & $>30,000$ \\
\hline $\begin{array}{l}\text { Grant Size } \\
\text { (Average Per Capita) }\end{array}$ & $\begin{array}{c}\text { Rpl00m } \\
\text { (Rp22,000) }\end{array}$ & $\begin{array}{l}\text { Rp250m } \\
(\mathrm{Rp} 24,000)\end{array}$ & $\begin{array}{l}\text { Rp500m } \\
(\mathrm{Rp} 27,000)\end{array}$ & $\begin{array}{l}\text { Rp750m } \\
(\mathrm{Rp} 28,000)\end{array}$ & $\begin{array}{l}\text { Rpl,250m } \\
\text { (Rp29,000) }\end{array}$ \\
\hline $\begin{array}{l}\text { Microcredit Fund for Group and } \\
\text { Indivuduals } \\
\text { Facilitators hired by OC (Oversight } \\
\text { Consultant): }\end{array}$ & $<\mathrm{Rp} 7 \mathrm{~m}$ & $<\mathrm{Rpl0m}$ & $<\mathrm{Rp} 20 \mathrm{~m}$ & $<\mathrm{Rp} 30 \mathrm{~m}$ & $<\mathrm{Rp} 50 \mathrm{~m}$ \\
\hline Kelurahan Facilitators & $0.5-1$ & 1 & $1-2$ & 2 & $3-4$ \\
\hline $\begin{array}{l}\text { Community Facilitators } 1 / 5000 \\
\text { Persons }\end{array}$ & 1 & $2-3$ & $3-4$ & $4-5$ & 6-8 \\
\hline
\end{tabular}

\section{REMUNERATION}

- Kelurahan Facilitator: hired by consultant for 24 months, paid Rp500, 000 per month plus $2 \%$ of the value of subprojects approved in parallel to disbursements from BRI. (OC are at district/sub-district)

- Community Trainee Facilitator: volunteers screened and paid up to 6 months Rp100, 000/ month by the OC.

- Group Technical Assistant: asked by community groups to assist with preparation and implementation of subprojects and paid under the subproject funding (kelurahan funds) or by profit sharing.

Maximum allocation per RW

Subproject cost/group
: Rp100m.

: Minimum Rp5m; maximum Rp30m.

The ceiling level of Rp100 million per RW are not entitlements and may be redirected from kelurahans with low progress after 12 months. The grants will be allocated to each kelurahan 1 time under the project. The kelurahan grant is used for subloans for sustainable economic activities and for grants for upgrading and building small public infrastructures, by demand by 
community groups. Subprojects have to be proposed within 6 months of program launch in the kelurahan but funds can be used over 1 year from the date of the initial advance.

The economic activities to be covered is open. Examples of possible activities: urban agriculture; group training in the communities (a subloan can cover a stipend); equipment (such as sewing machines, computers); programs for children and youth; community based housing provided it can be done within 1 year; family planning education. Each kelurahan can also establish a microcredit fund to provide small revolving credits to individuals and groups. Microcredits can be requested for training-apprenticeships (training on the job where the employer may pay part of a minimum wage and a subloan pay the balance, for up to 6 months) and other public or private training programs, but such new street shops are discouraged. The following cannot be funded: arms, harmful drugs, depositing project funds in banks to earn interest, land acquisition, religious buildings, government administration, and environmentally harmful products.

Geographical coverage of UPP1 during the phases 1 and 2 were depicted in the following tables (pages 25-26).

Tabel 2: Kelurahan Coverage

A. Summary by Province on Java

Phase 1: Northern Java, Bandung, Yogyakarta, and Malang

Kelurahans with population $>7.500$

Start in January/February 1999

\begin{tabular}{|l|c|c|c|c|c|c|}
\hline \multicolumn{1}{|c|}{ PROVINCE } & $\begin{array}{c}\text { Tk II } \\
\#\end{array}$ & $\begin{array}{c}\text { Kecamatan } \\
\# \text { l/ }\end{array}$ & $\begin{array}{c}\text { Kelurahan } \\
\#\end{array}$ & $\begin{array}{c}\text { Grants } \\
\text { Rp Billions }\end{array}$ & $\begin{array}{c}\text { \# Kelurahan } \\
\text { Facilitators }\end{array}$ & $\begin{array}{c}1995 \\
\text { Population } \\
\text { Millions }\end{array}$ \\
\hline DKI Jakarta & 5 & 43 & 249 & 224 & 487 & 7.71 \\
\hline West Java & 15 & 192 & 542 & 203 & 587 & 7.94 \\
\hline Central Java & 17 & 153 & 174 & 55 & 181 & 2.11 \\
\hline East Java & 17 & 191 & 242 & 98 & 286 & 3.71 \\
\hline DI Yogyakarta & 5 & 47 & 98 & 30 & 103 & 1.21 \\
\hline \multicolumn{1}{|c|}{ All } & 59 & 626 & 1,305 & 610 & 1,644 & 22.7 \\
\hline
\end{tabular}

Phase 2:

Northern Java, Bandung, Yogyakarta, and Malang

Kelurahans with population $<7.500$

Eligible Kelurahan, to start about September 1999

\begin{tabular}{|l|c|c|c|c|}
\hline PROVINCE & $\begin{array}{c}\text { Additional Kecamatan } \\
\#\end{array}$ & $\begin{array}{c}\text { Kelurahan } \\
\#\end{array}$ & $\begin{array}{c}\text { Grants } \\
\text { Rp Billions }\end{array}$ & $\begin{array}{c}1995 \\
\text { Population } \\
\text { Millions }\end{array}$ \\
\hline DKI Jakarta & 0 & 16 & 1.6 & 0.09 \\
\hline West Java & 11 & 400 & 40.0 & 2.06 \\
\hline Central Java & 2 & 569 & 57.9 & 2.37 \\
\hline East Java & 18 & 528 & 53.8 & 2.10 \\
\hline DI Yogyakarta & 0 & 27 & 2.7 & 0.15 \\
\hline \multicolumn{1}{|c|}{ All } & +31 & 1,540 & 154 & 6.7 \\
\hline
\end{tabular}

\section{"Southern" (rest) of Java}

\begin{tabular}{|c|c|c|c|c|c|c|}
\hline PROVINCE & $\begin{array}{c}\text { Tk II } \\
\#\end{array}$ & $\begin{array}{c}\text { Kecamatan } \\
\text { \# 1/ }\end{array}$ & $\begin{array}{c}\text { Kelurahan } \\
\#\end{array}$ & $\begin{array}{l}\text { Kelurahan } \\
\quad<7,500\end{array}$ & $\begin{array}{c}\text { Grants } \\
\text { Rp Billions }\end{array}$ & $\begin{array}{c}1995 \\
\text { Population } \\
\text { Millions }\end{array}$ \\
\hline West Java & 11 & 87 & 292 & 265 & 35.5 & 2.05 \\
\hline Central Java & 18 & 168 & 570 & 384 & 94.4 & 3.42 \\
\hline East Java & 20 & 142 & 498 & 403 & 68.3 & 2.75 \\
\hline All & 49 & 397 & 1,360 & 1,052 & 198.2 & 8.22 \\
\hline
\end{tabular}

Note: Kelurahans also comprise urban villages, as classified by BPS. 
Witjaksono, Mit (2015). The Miniature of Siparti 3-S: KSM Sibermas in the Urban Poverty Project in Kelurahan Tlogomas, Kecamatan Lowokwaru, Malang, Indonesia. Archives of Business Research, 3(2), 199-217.

B. Summary by Kelurahan Size

\begin{tabular}{|c|c|c|c|c|c|c|c|}
\hline KELURAHAN & Very Small & Small & Medium & Large & Very Large & $\begin{array}{c}\text { Total w/o } \\
\text { Very Small }\end{array}$ & Total \\
\hline Population Tresholds & $<7,500$ & $\begin{array}{l}7,500- \\
15,000\end{array}$ & $\begin{array}{l}15,001- \\
22,500\end{array}$ & $\begin{array}{l}22,501- \\
30,000\end{array}$ & $>30,000$ & & \\
\hline Grant/Kelurahan & Rp100m & Rp250m & Rp500m & Rp750m & $R p 1.250 m$ & $R p 1,250 m$ & \\
\hline Average/Capita & Rp22,000 & Rp2,.500 & Rp27,300 & Rp28,750 & \begin{tabular}{|l|}
$R p 29,200$ \\
\end{tabular} & Rp26,000 & \\
\hline \multicolumn{8}{|l|}{ "Northern Java" } \\
\hline \# Kelurahan & 1,540 & 760 & 266 & 123 & 156 & 1,395 & 2,845 \\
\hline 1995 Population & $6.7 \mathrm{~m}$ & $7.9 \mathrm{~m}$ & $4.9 \mathrm{~m}$ & $3.2 \mathrm{~m}$ & $6.7 \mathrm{~m}$ & $22.7 \mathrm{~m}$ & $29.4 \mathrm{~m}$ \\
\hline Grants & Rp105.2bn & Rp190.0bn & Rp133.0bn & Rp92.3bn & Rp195.0bn & Rp610.3bn & Rp764.3bn \\
\hline \multicolumn{8}{|l|}{ "Southern Java" } \\
\hline \# Kelurahan & 1,052 & 266 & 28 & 10 & 4 & 308 & 1,360 \\
\hline 1995 Population & $4.7 \mathrm{~m}$ & $2.7 \mathrm{~m}$ & $0.5 \mathrm{~m}$ & $0.3 \mathrm{~m}$ & $0.1 \mathrm{~m}$ & $3.6 \mathrm{~m}$ & $8.3 \mathrm{~m}$ \\
\hline Grants & Rp105.2bn & Rp66.6bn & Rp14.0bn & Rp7.5bn & \begin{tabular}{|l|} 
Rp5.0bn \\
\end{tabular} & Rp10.4bn & Rp473.6bn \\
\hline \multicolumn{8}{|l|}{ "Off-Java" } \\
\hline \# Kelurahan & 2.301 & 609 & 114 & 35 & 28 & 786 & 2.817 \\
\hline 1995 Population & $7.3 \mathrm{~m}$ & $6.2 \mathrm{~m}$ & $2.1 \mathrm{~m}$ & $0.9 \mathrm{~m}$ & $1.1 \mathrm{~m}$ & $10.4 \mathrm{~m}$ & $17.7 \mathrm{~m}$ \\
\hline Grant cost & Rp203.1bn & \begin{tabular}{|l|} 
Rp152.32b \\
$\mathrm{n}$
\end{tabular} & Rp57.0bn & Rp26.3bn & Rp35.0bn & Rp270.5bn & Rp473.6bn \\
\hline \multicolumn{8}{|l|}{ Indonesia Total } \\
\hline \# Kelurahan & 4,263 & 1,635 & 408 & 168 & 188 & 2,399 & 7,022 \\
\hline 1995 Population & $18.7 \mathrm{~m}$ & $16.8 \mathrm{~m}$ & $7.5 \mathrm{~m}$ & $4.4 \mathrm{~m}$ & $7.9 \mathrm{~m}$ & $36.7 \mathrm{~m}$ & $55.4 \mathrm{~m}$ \\
\hline Grant cost & Rp462.3bn & Rp408.7bn & Rp204.0bn & Rp126.0bn & Rp235.0bn & Rp973.9bn & Rp1,436.2bn \\
\hline
\end{tabular}

Shaded: Phase 1

Off-Java and Total Indonesia shown for information only.

KSMs as eligible groups formed for economic activities should have at least 3 members (different households); incomes of a family of 4 should be less than about Rp250,000 per month (this amount may be adjusted with inflation by year 2; to attract higher skills, up to a third of the members may have higher incomes); some BKKBN poverty criteria would also apply (is the household head working; is the spouse working; do they rent the house; quality of house). Membership of the KSM would be agreed by the Kelurahan Forum (KF) . Each group/person can get funds only once (at least until there are no acceptable proposals by new groups/persons). Women are encouraged to participate and shall have equal opportunity. Subloans have to be repaid within a year, with interest at the commercial rate prevailing for one year loans; the repayment schedule should reflect the cash flow of the financed activity. The repayments are to be deposited in a KF account in a local bank of the KF choice, in its name, for revolving following the same principles. This local bank has to be willing to let designated staff attend some KF meetings. The accounts shall not have ATM cards. Half of the interest accrued should be used to help finance maintenance of local public infrastructure; another part should be used to help finance administration of the KF.

\section{The Establishment of BKM Tlogomas and KSM Sibermas in the Second Phase of UPP1}

Geographically Malang is divided into two governmental areas: Kabupaten Malang (Malang District) and Kota Malang (Malang City). Both areas had been established as the coverage area of the first and second phases. According to the "Daftar Kelurahan Sasaran P2KP Tahap 1" (see page 33, World Bank PAD, 1999), Kelurahan Tlogomas (under the Kecamatan Lowokwaru) was listed as "Small Population Thresholds" which granted in the amount of Rp250m.

In the early of second phase (started in 2000), FK of Tlogomas finally established on February 23, 2000 under the name of BKM Tlogomas, which eventually administer all the projects (http://www.bkmtlogomas.com/profil). Soon after the establishment of BKM Tlogomas, KSM Sibermas was established in March 12, 2000, situated at RW-08, Kelurahan Tlogomas. This KSM was the only community group which it's focused on empowering the poor and skilled- 
unemployment peoples by giving a series of appropriate training program. KSM Sibermas was actually an ad-hoc community group within duration of one term only under the second phase of UPP1 (i.e. from March 2000 to June 2001).

\section{The Background}

\section{KSM SIBERMAS IN ACTION}

The idea of forming and establishing KSM Sibermas was inspired and motivated by the previous successful of the author in executing a training program for the retrenched tertiary graduates who had lost their jobs due to the financial crisis during 1998, under the project was known as P3T - Proyek Penanggulangan Pengangguran Pekerja Terampil (Skilled Workers Unemployment Project) (Witjaksono, 1998a \& 1998b). Based on this experience, the Head of BKM Tlogomas asked the author to participate in the area of training to the targeted poor community around Kelurahan Tlogomas.

In response to the inquiry of BKM Tlogomas, on early March 2000 the author started to act by writing and submitting a proposal of forming a KSM called Sibermas. The proposal was approved by BKM Tlogomas, and in March 12, 2000 the KSM Sibermas formally established. The word "Sibermas" (Sinergi Pemberdayaan Masyarakat, or Synergy of Community Empowerment) refers to twofold meaning: as a synergy in empowering process and as products resulted from synergistically efforts. It was hoped that KSM Sibermas be one of the key vehicles and agents of change in developing capacity of local poor community group. The spirit underlying the emergence of KSM Sibermas was "from the people, by the people, and for the people".

\section{Road to Accomplish the Mission}

Following the establishment of KSM Sibermas, the author together with all members (8 persons of RW-08 residents) started to plan a series of actions regarding the main task of providing and delivering appropriate training to the targeted group as inquired by BKM Tlogomas. There were four main activities agreed to act: (i) gathering preliminary basic information about targeted group of training, (ii) mapping and analyzing available resources to be the basis of training activities, (iii) analyzing and deciding the scheme of training looks alike, and (iv) CONFIGURING the overall training activities into a comprehensive plan of action. These activities were executed within three months (April - June, 2000). The preliminary results were then formulated into a proposal under the title of "Usulan Kegiatan: Pelatihan Pemanfaatan Limbah untuk Pembuatan Aneka Produk yang Ekonomis dan Berwawasan Lingkungan" (Action Proposal: Training of Utilizing Waste Materials to Create Economically and Environmental-Friendly Products), and approved by BKM Tlogomas on June 30, 2000.

The descriptions about the reasons, objectives, participants, time and place, tools and equipment, organization, and scenario of all training activities described below are derived from the approved proposal (see more detailed in Witjaksono, 2000, Annex A, pp. 1-6).

Why utilizing waste materials and creating products that sound economically and environmental-friendly?

The waste materials handling, especially garbage, in the city of Malang seems increasingly complicated and complex. Various parties have participated submit ideas, suggestions and efforts to resolve it, both technically and non-technically, as implied from some local newspaper clippings (Jawa Pos - Radar Malang, from April 24 to June 24, 2000, cited in References of this article). In the area of Kelurahan Tlogomas (coverage of 9 RWs), the potentials of garbage that temporary dumped into TPS (Tempat Pembuangan Sementara, or Temporary Waste Disposal/Dump, located at RW-08, see Witjaksono, 2000, Annex D2) had not 
been used for the economic purposes which were eventually giving a direct impact on environmental preservation efforts, the creation of business and job opportunities, and as a pilot model of self-management in waste materials handling.

\section{What the objectives and expected changes conditions of the training?}

The main objectives of the proposed training: (i) to provide participants a set of knowledge, skills, and attitudes were required in the poverty reduction on the basis of utilization waste materials available around settlement participants, (ii) to encourage residents Kelurahan Tlogomas to aware of, care for, and willing to try to solve their economic problems independently, and (iii) to initiate a pattern of community empowerment through the management of processing and marketing of the products resulted from utilizing waste materials. The expected changes conditions during and after the training took place: (iv) the growing awareness, understanding, and interest among the participants for pioneering economic empowerment independently based on their potential development capacity and are available in the neighborhood, (v) the formation of self-initiated groups of economicproductive in each RW among the alumni participants synergistically with other residents in an effort to increase social welfare, economy, and culture, (vi) the establishment of a pilot model of waste materials handling (especially garbage) in Kelurahan Tlogomas neighborhood, which had a key feature that initiative, carried out by, and the results/benefits to the local community, and (vii) the creation of togetherness climate in order to tackle the problem of poverty, which in turn can increase the brotherhood and unity among people of Kelurahan Tlogomas.

\section{Who were the training participants?}

Prospective trainees were residents of Kelurahan Tlogomas (RW-01 to RW-09) who meet the following criteria:

1. Did not have a permanent job and have to support their family life, including here who were "unemployed skilled workers".

2. Having a permanent job, but relative income was always insufficient to meet the needs of family dependents (including here the "waste pickers" or "scavengers").

3. They were classified as (1) and (2) which were not currently being probation or internship in an institution/agency/business company.

The number of participants was planned to reach 60 (sixty) people, with the approximated composition: 40 men and 20 women. Among the 40 men, about 20 people were the garbage collector taskforce from every RT \& RW of Kelurahan Tlogomas.

\section{Where, when, and how long the training conducted?}

The training were conducted in four locations:

1. The Metting Hall of Kelurahan Tlogomas.

2. The spaces available around the TPS (RW-08).

3. The back yard of Al-Ghozali Mosque (RW-08).

4. Homes designated by each group of participants.

The starting training was scheduled beginning on January 2001 and ending on April 2001 (four moths effective).

\section{Who organized and supported the training?}

The founders of KSM Sibermas was assigned as the ad-hoc committee for the implementation of the training. The structure of organization of the committee consisted of the Chairman (the author himself), Secretary, Treasurer, and assisted by 3 persons who were respectively 
responsible for provision and preparation of equipment and tools, on site demonstration, and documentation of all activities. They were all residents of RW-08.

There were five persons who were in charge as the training facilitators and consultants as well. They were came from experts group of INBISTEK (Inkubator Bisnis dan Teknologi, or Business and Technology Incubator) of LPM UM (Lembaga Pengabdian kepada Masyarakat, Universitas Negeri Malang), or the Institute of Service to the Community, State University of Malang. Three of them were assigned respectively to train in (a) composting the garbage, (b) recycling papers, and (c) handicraft based on recycled papers and other waste materials. Two of them were assigned to train participants of how to operate and maintain a machine that used in shredding and mixing garbage raw materials of composting.

\section{What kind of training activities and how they designed?}

The training activities were classified into three clusters: (i) composting (i.e. making compost from garbage available in the TPS), (ii) recycling papers (i.e. recycling the papers mainly from the collection of the waste-pickers and from the households of RW-08), and (iii) handicrafting (i.e. making a various crafts as the result of combining recycled papers - from the second cluster, and various raw materials provided by participants themselves).

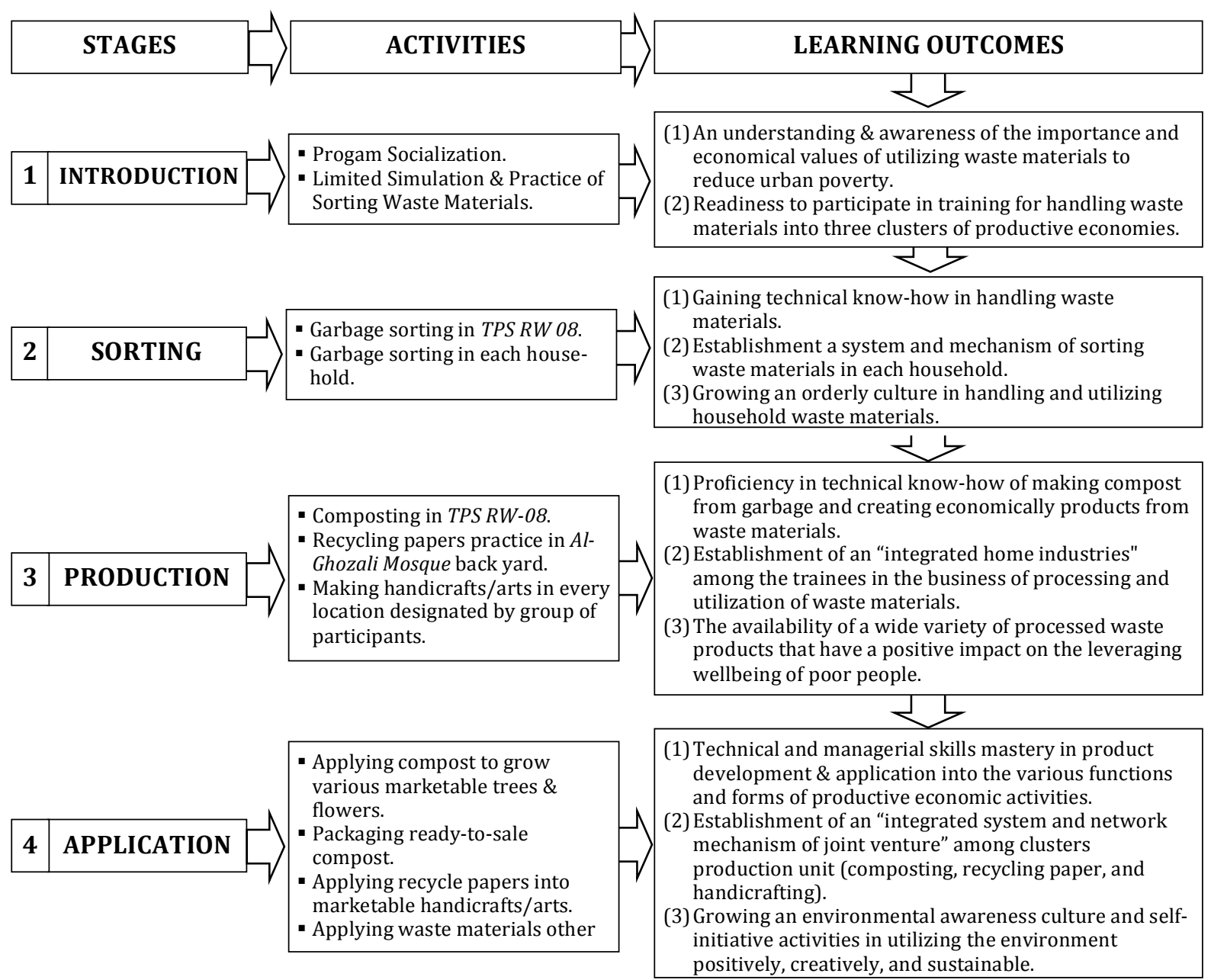

Figure 1: Training stages, activities, and learning outcomes

(Adapted from Witjaksono, 2000: 5)

Stage 1- Introduction. Socialization or familiarization about what, why, and how utilization of waste materials became one of the easiest, fasted, most efficient and effective, of alternative in response to the poverty alleviation. After the socialization was completed, followed by a limited simulation of how the processes and techniques of sorting the waste materials those 
usually available around the participants' house. The next action was a simple ways to identify, sort, and classify the waste materials based on their nature and potentials to be processed into the "3-Rs" (reusing, recycling, and reforming/reassembling) (as configured in Figure 2). Activity followed by limited simulation sorting practice by participants with solid waste materials (compiled solely by each participant). Activities ended with workshops and consultation meetings together to develop an action plan, such as forming small groups based on the participant's interests and abilities, the determination the place/location of group activities, physical preparation (materials, tools, equipment, setting up of location, the coordination of activities, and scheduling of group activities) which was required as the activities reference to the later stages (Stages 2, 3, and 4).

Stage 2 - Sorting. It was the sorting and grouping practice of waste materials in locations specified (as decided on the Stage 1). During this stage, all trainees practicing the techniques and procedures informed by the trainers/facilitators, while the consultants monitoring and evaluating how well the action plan had been accomplished, and giving an advice how to cope with problems encounter.

Stage 3 - Production. It was the production process of composting, recycling paper, and making handicraft/arts on locations/places as designated by each group. During this stage, the trainers, facilitators, and consultants were always accompanying and giving technical advices in order to achieve optimal result.

Stage 4 - Application. It was the advance of application production achieved during Stage 3. In this stage, there were one or more follow-up steps to go before the "end products" economically saleable. During these follow-up activities facilitators and consultants provide guidance and technical assistance in building and running a system of production process, doing feasibility study of the possibility to form and operate such a network of cooperative business among the three clusters of strategic business unit (composting, recycling paper, and handicraft/arts), and marketing planning.

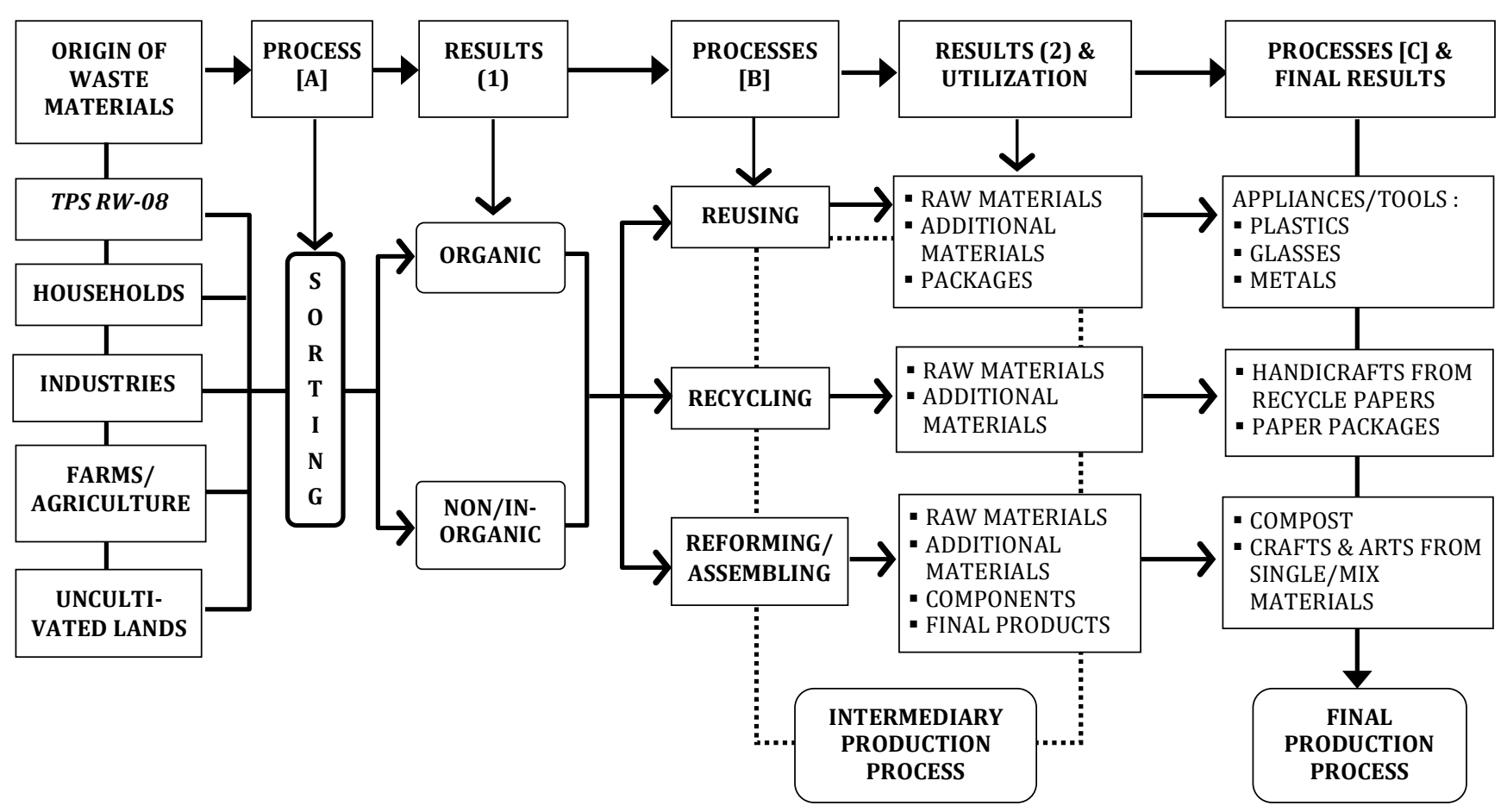

Figure 2: The scheme of waste materials utilization processes (Adapted from Witjaksono, 2000: 6) 
The origin of waste materials on the left side shows that beside those already available (pooled) in the TPS RW-08; there were four other pool resources such as households, industries, farms/agriculture, and uncultivated lands nearby the location of training carried out. All the waste materials first of all sorted into two types as identified as organic materials and non/inorganic materials (Process A \& Result 1). Then, the results were processed through "3Rs" (Processes B), to obtain a various intermediary products (from reusing and recycling) and final products (from reforming/reassembling), those were potentially having economical and adding values to other next production processing. Some of the intermediary results finally processed into the final production processes (Processes C \& Final Results).

\section{Figures $3 \& 4$ show the situations and physical appearances of where the waste materials originated, location, and site facilities for composting training.}
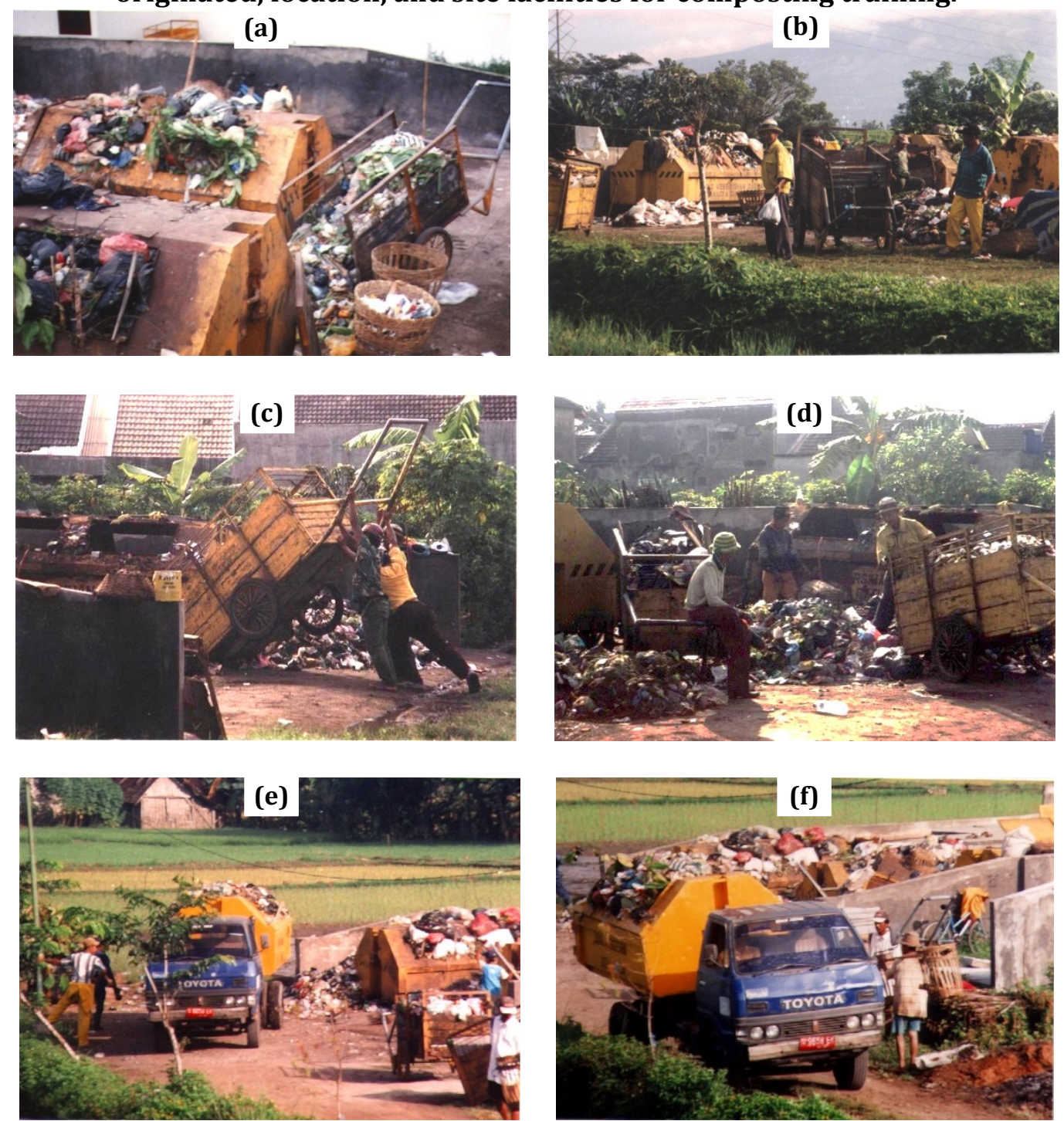

Figure 3: The daily activities in TPS RW-08

(Pictures taken during site exploration in March 11-12, 2000)

(a) The collection of garbage already in the dump vessels (bin and wagon/push-cart). Garbage in the wagon/push-cart (totally 20 carts everyday) collected from 9 RTs within the RW-08 area.

(b) The garbage collectors (local term: pasukan kuning, due to their yellow uniform) ready to work.

(c) \& (d) unloading garbage from the wagon and loading it to the garbage bin vessel by pasukan kuning. 
(e) \& (f) garbage bin loaded to the garbage truck and carried to the final disposal place.
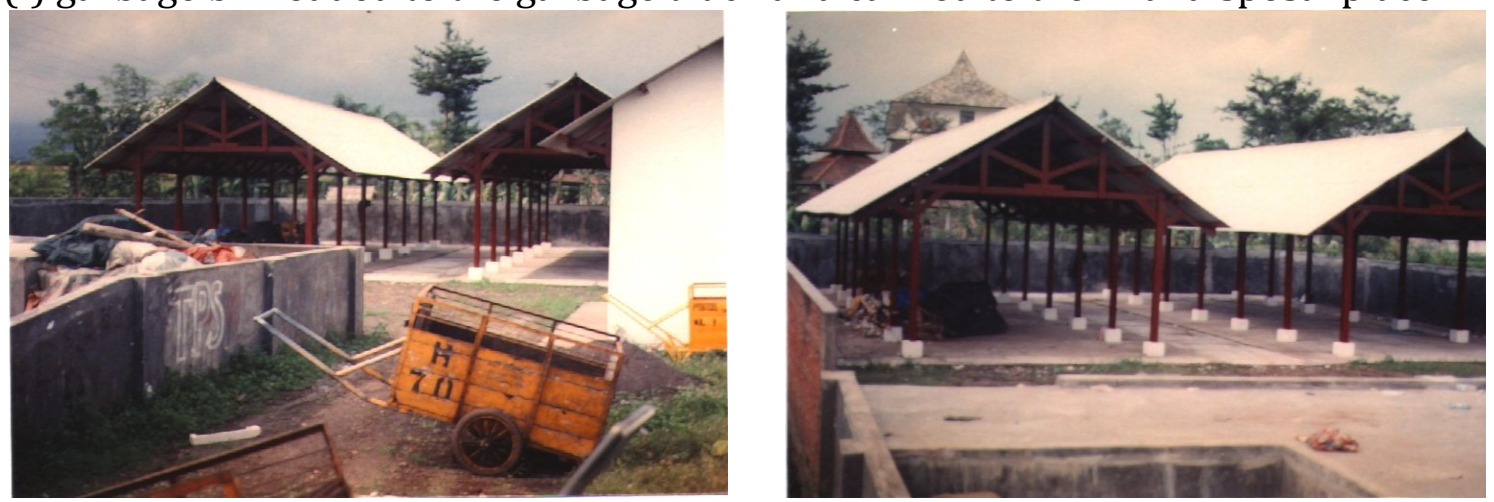

Figure 4: The newly buildings for processing the garbage in TPS RW-08 (Pictures taken during site exploration in March 11-12, 2000)

This newly buildings (in the back side of dumping area on Figure 3) were finished at the end of November 1999 and spesifically designated to composting process by Kelurahan Tlogomas.

\section{The Snapshots of Training Execution}

The following pictures taken during the execution of onsite training (January - March 2001, see Witjaksono, 2001).

[A] Figure 5: Composting (pictures 1 through 17) The trainer gave an exposition about the basics of composting technical know-how (See Dharmawan, 1999)
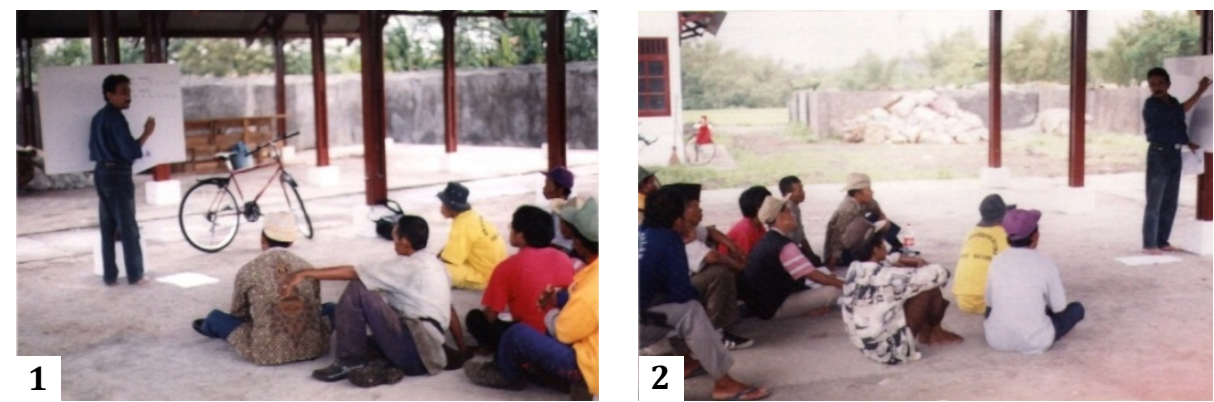

Sorting practice of garbage from one wagon
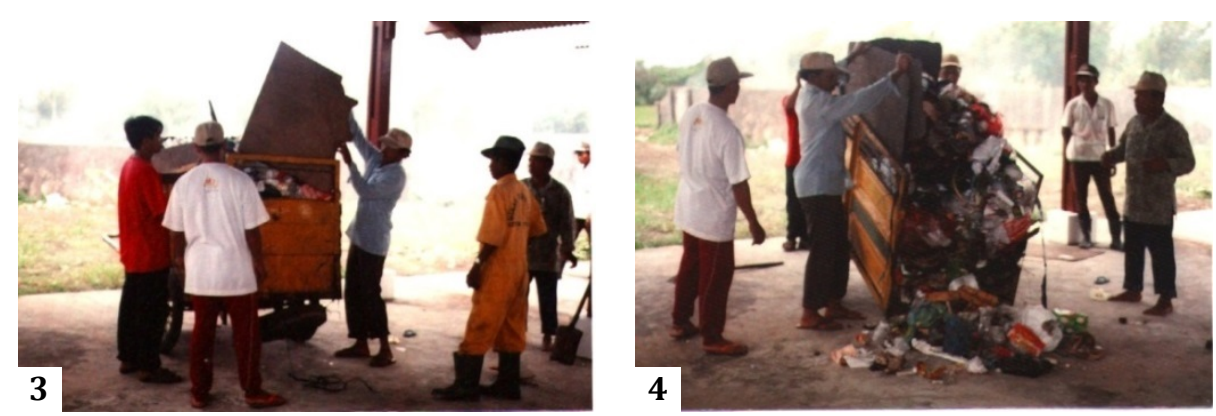

Sorting practice of garbage continued ... 

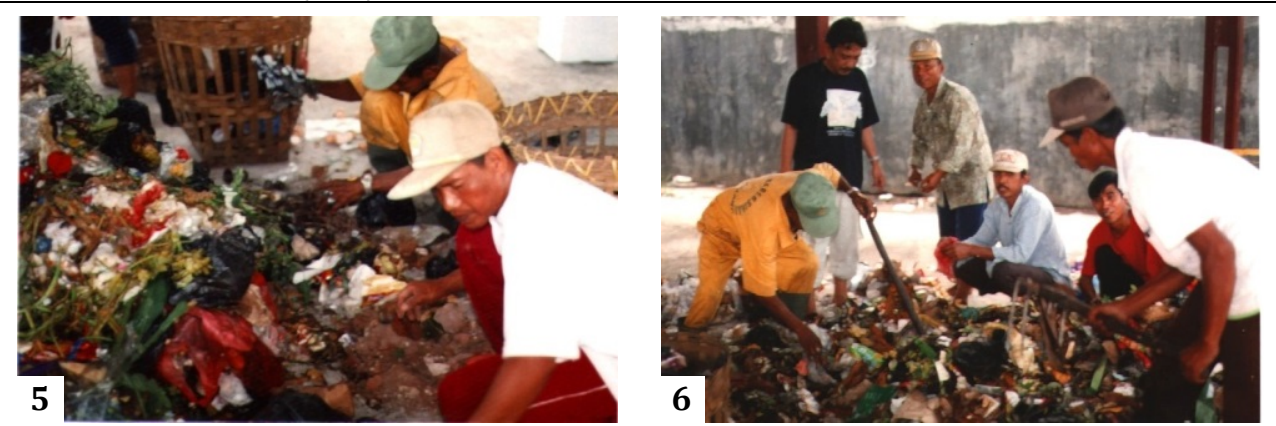

Sorting practice of garbage continued and the final result as raw materials of compost
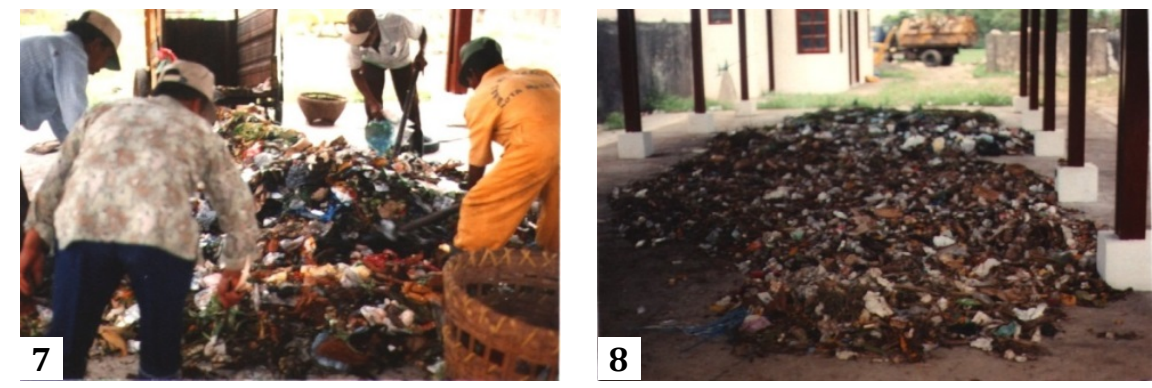

The trainee gave a guide about how to operate the shredding machine
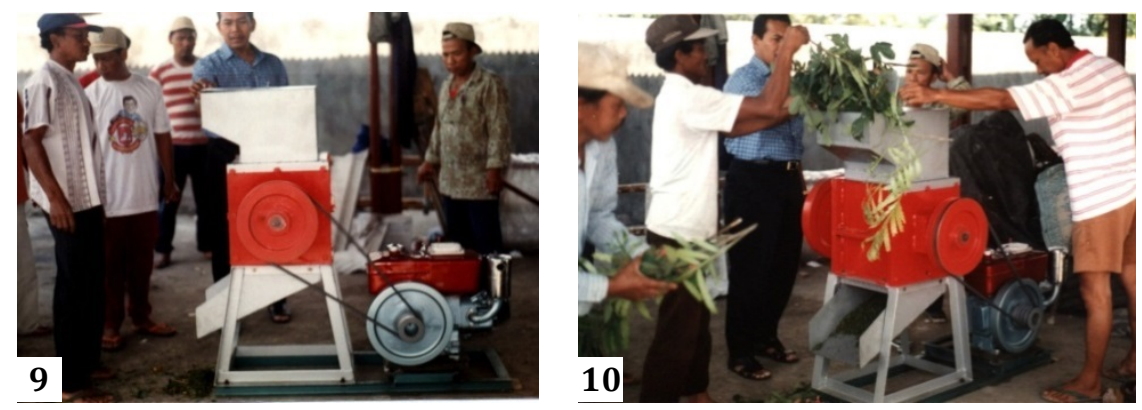

Shredding practice of raw materials (as picture 8) and final product ready to decomposed
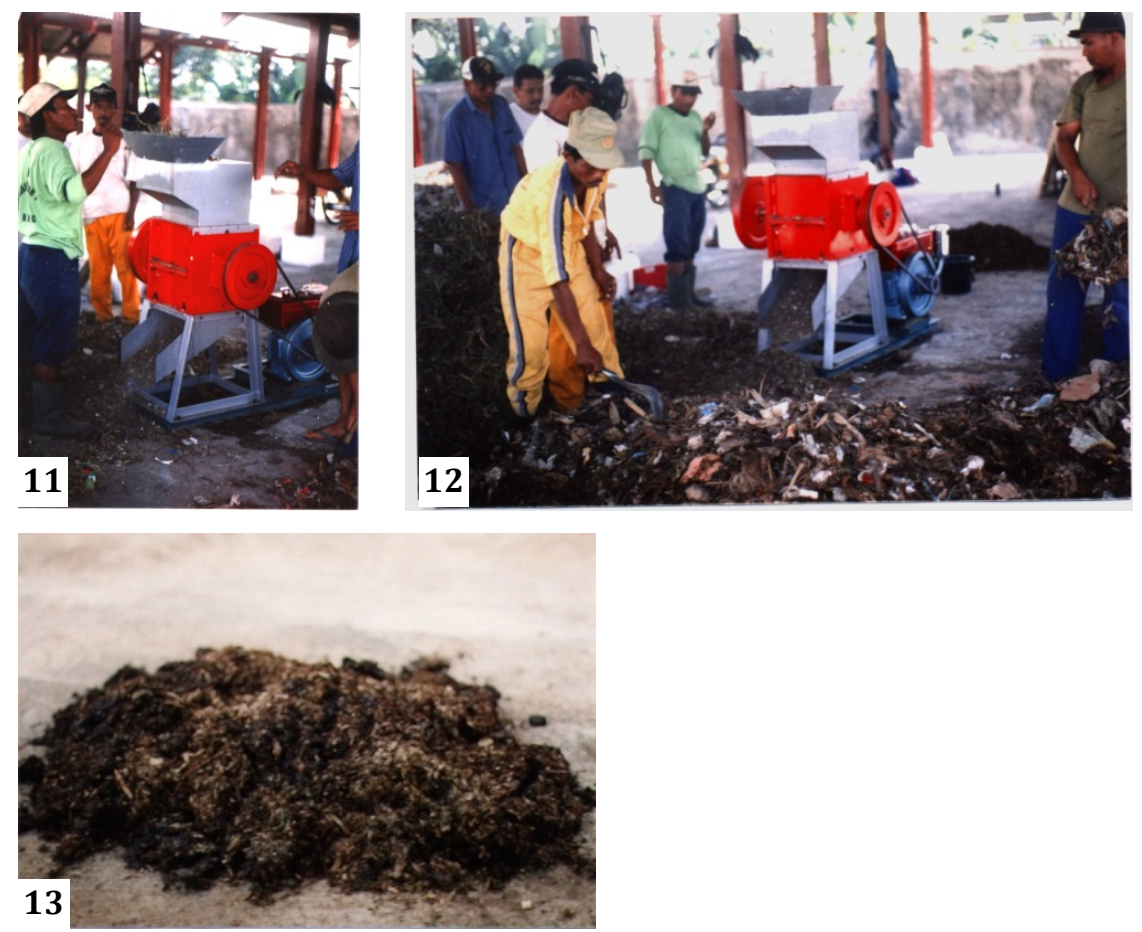

Mixing the raw materials (picture 13) with additional materials to be decomposed into compost pile 

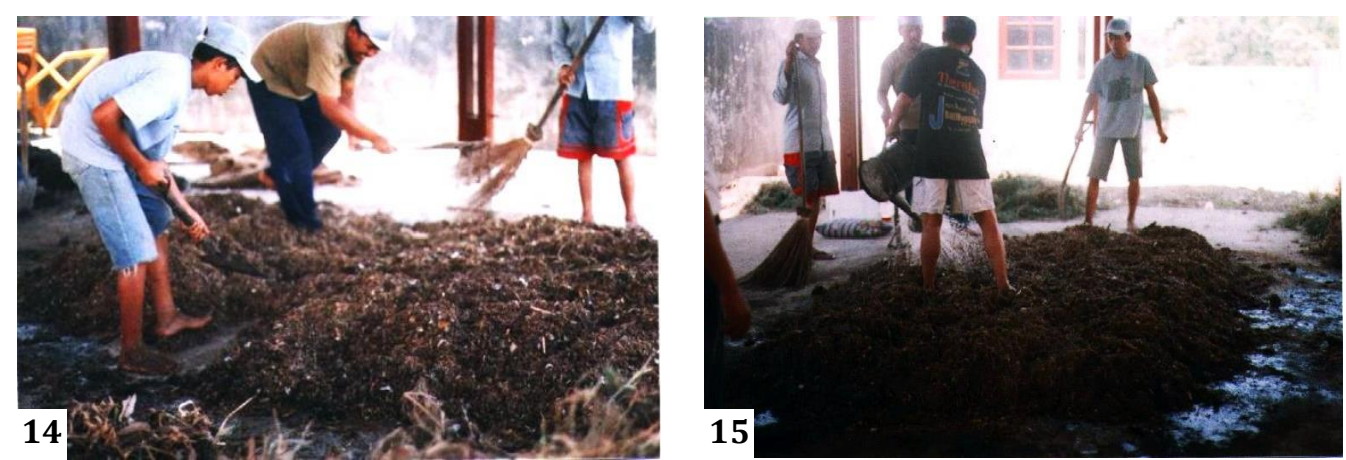

Compost piles before refined (picture 16) and after refined (picture 17)
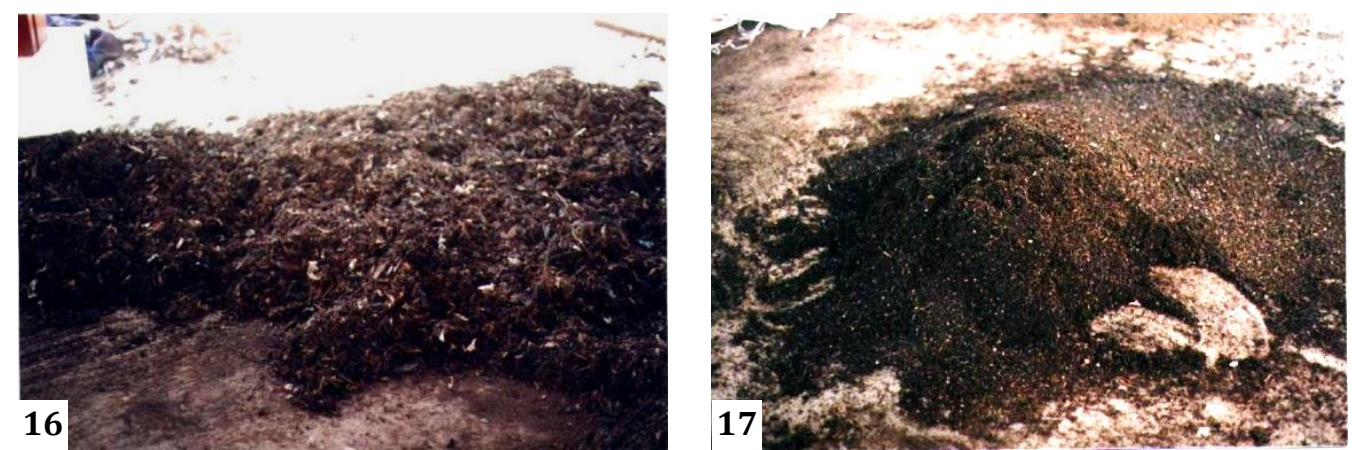

[B] Figure 6: Recycling Papers (pictures 18 through 24)

Tools \& equiments for recycling paper (picture 18) and the pulp of paper ready to blended/mixed

(See Kustiawan, 1999)
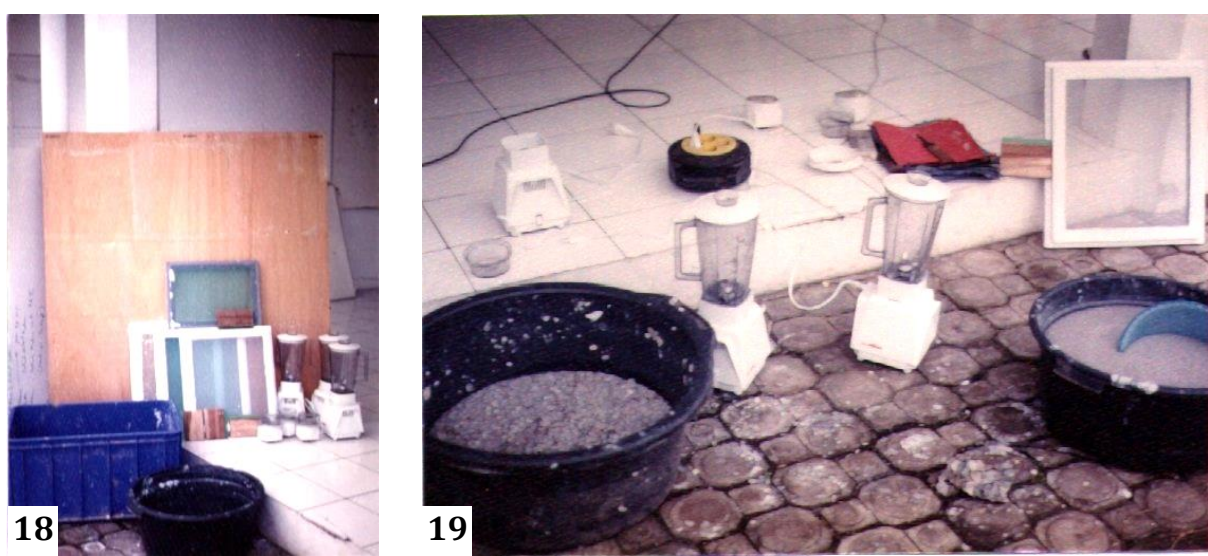

Blending and mixing pulp with color and other additional materials (such as dried grass and leaf clippings) 

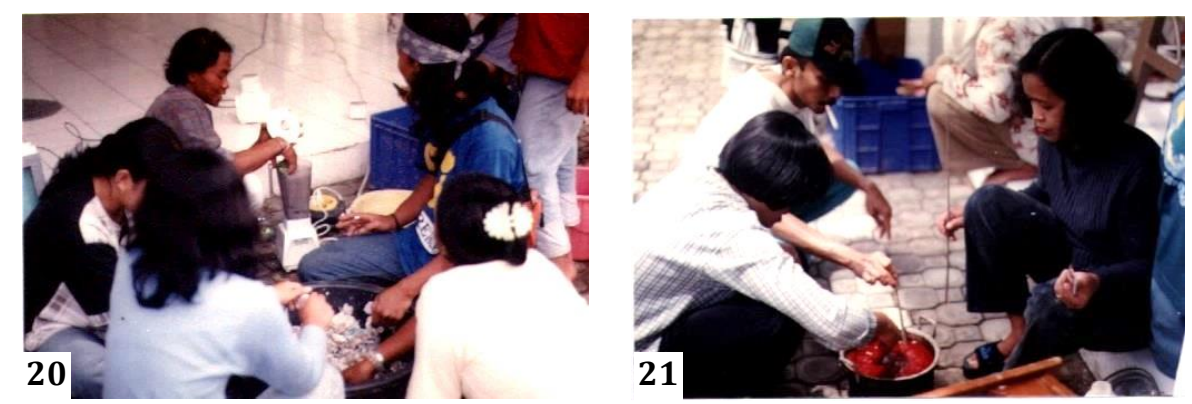

Making a piece of recycled paper from the pulp by a screen to print on the surface of a wooden board
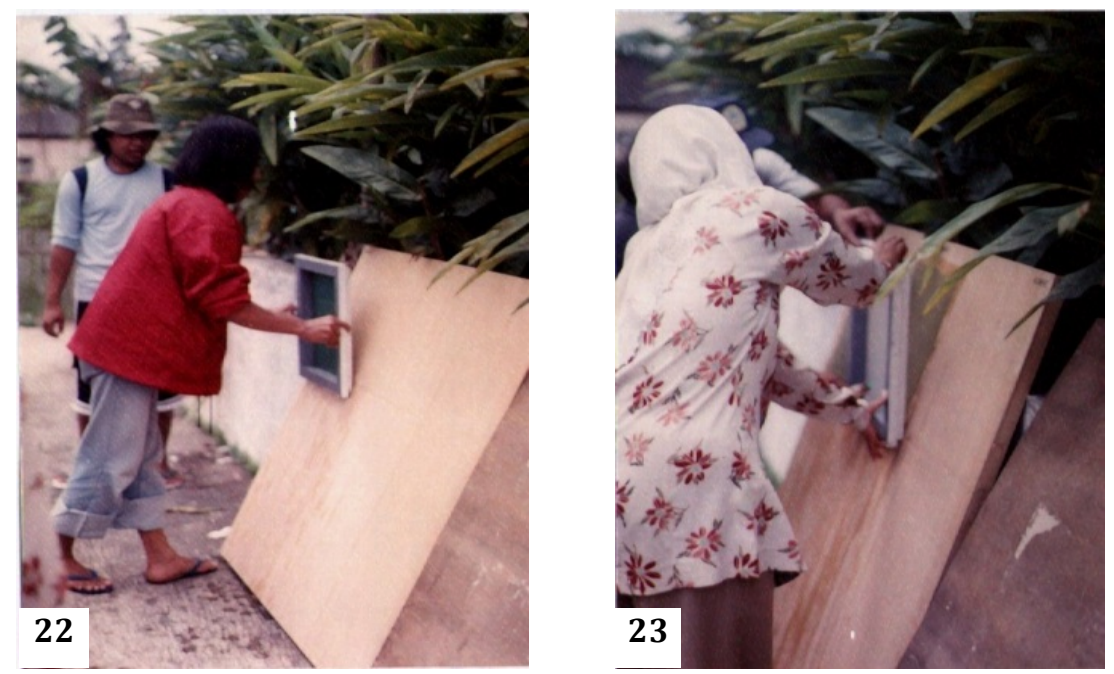

Recycled papers ready to sell or to be used as materials for handicrafts
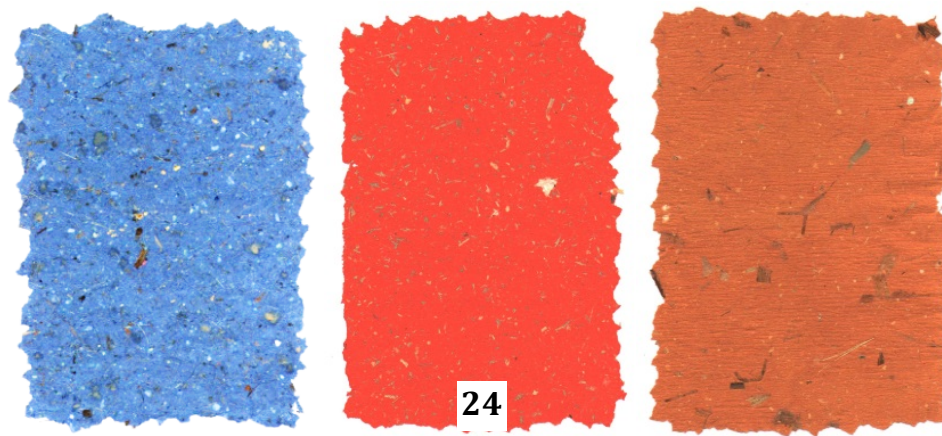

[C] Figure 7: Crafting the Recycled Papers (pictures 25 through 29) Making various picture frames from recyled papers
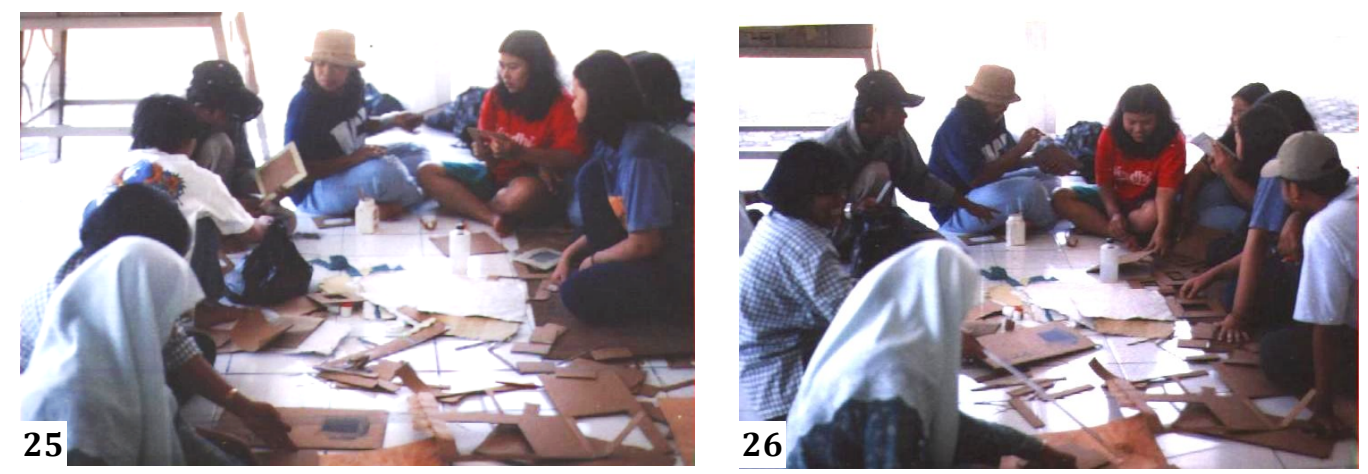

Various picture frames 

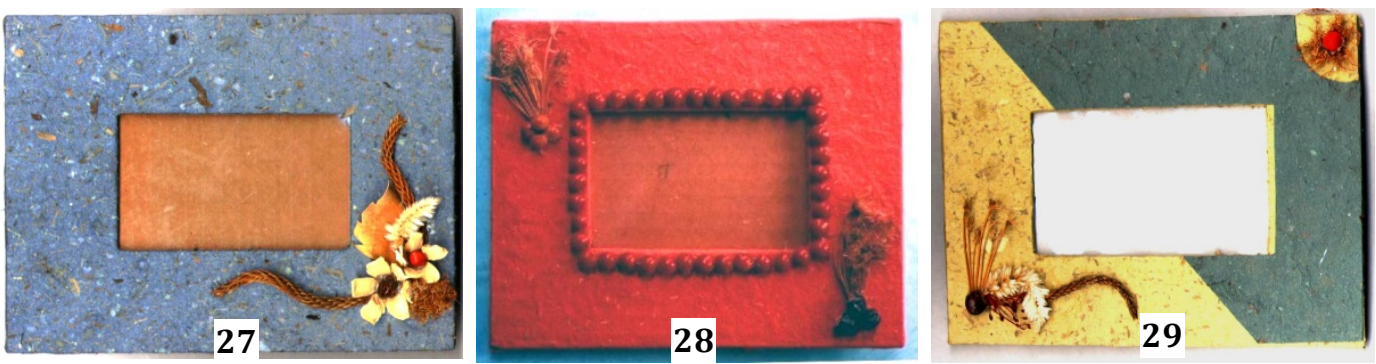

\section{KSM SIBERMAS AS THE MINIATURE OF SIPARTI 3-S}

\section{An overview of Siparti 3-S}

Siparti 3-S is the acronym of Sinergi Partisipatori 3 Sumberdaya - Synergistic Participatory of the 3 Resources (human, natural/environment, and social/culture). The term Siparti 3-S was introduced at the first time in 1997 when the author presented a proposal to induce the implementation of the GKD (Gerakan Kembali ke Desa - Back to Village Movement) - a project initiated and declared by Basofi Sudirman (as the governor of East Java Province at that time) (Witjaksono, 1997) . At the second time, the term Siparti 3-S was introduced by the author when executing a series of training for the retrenched tertiary graduates who had lost their jobs due to the financial crisis during 1998, under the project of P3T - Proyek Penanggulangan Pengangguran Pekerja Terampil (Skilled Workers Unemployment Project) (Witjaksono, 1998a \& 1998b). The last time Siparti 3-S was introduced when the author reviewed critically the issue and the role of the so-called "triple helix model" and "social capital" into the problems of how to strengthen local competitive industries in Indonesia (Witjaksono, 2012 \& 2014).

The notion that underlying Siparti 3-S proposed in inducing GKD was how to integrate functionally and effectively all potencies and capacities resources available in every village under the GKD project. Resources were considered to be the foundation of each village competitiveness were the basic resources, which already there, owned, controlled, and managed by the stakeholders in the villages, namely: (a) human resources (HR), (b) natural resources/physical environment (NR/PE), and (c) social and cultural resources (SR\&CR).

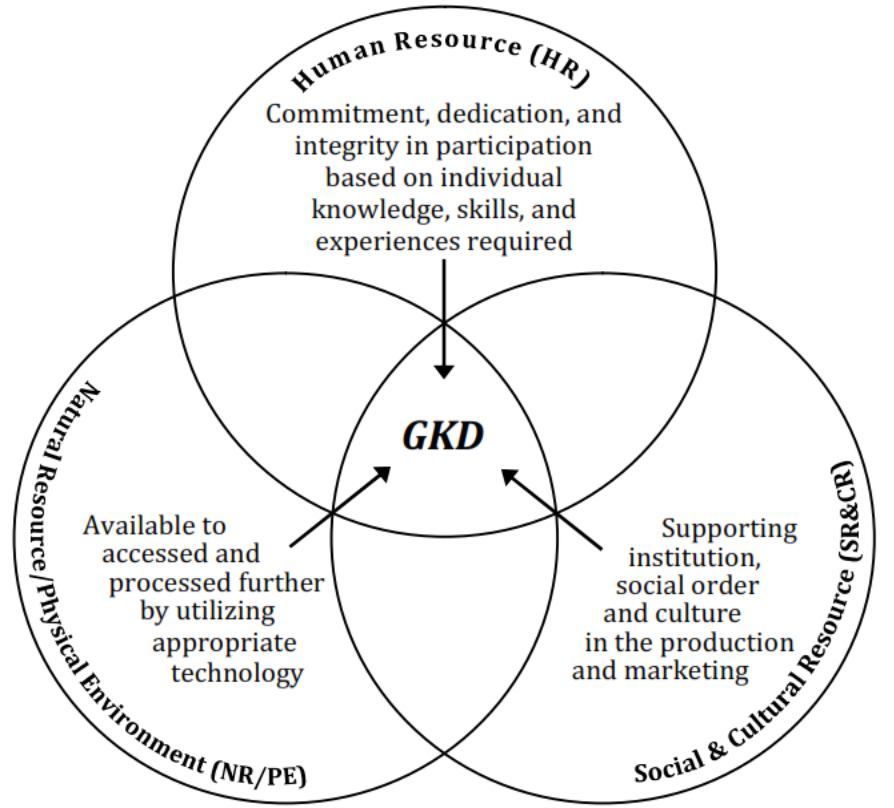

Figure 8: GKD seen as a synergistic participatory project (Source: Witjaksono, 1997: 5) 
GKD can be seen as a full synergistic participatory whenever the following conditions of each resource exist (Witjaksono, 1997, 1998a, 2012, and 2014):

a) HR was the people living in the village who have knowledge, skills, and experience required, with commitment and strong integrity to dedicate to the various efforts to achieve GKD.

b) NR/PE was the existing of natural resources or physical environment available in the village those that relatively easy to access and process under the circumstances of implementation of appropriate systems and technologies.

c) SR was social resources that directly or indirectly support the continuity of the process production under the scheme of GKD, in the form of institutions (social or business) including the social order inherent in it.

d) CR was the local cultural resources that sustains and/or become nurturing products of the entire activities GKD.

In the context of P3T, the above conditions were also required in training for the newly/startup entrepreneurs, however, under the reciprocal or exchange interactions as shown by " $\leftrightarrow$ " in Figure 9.

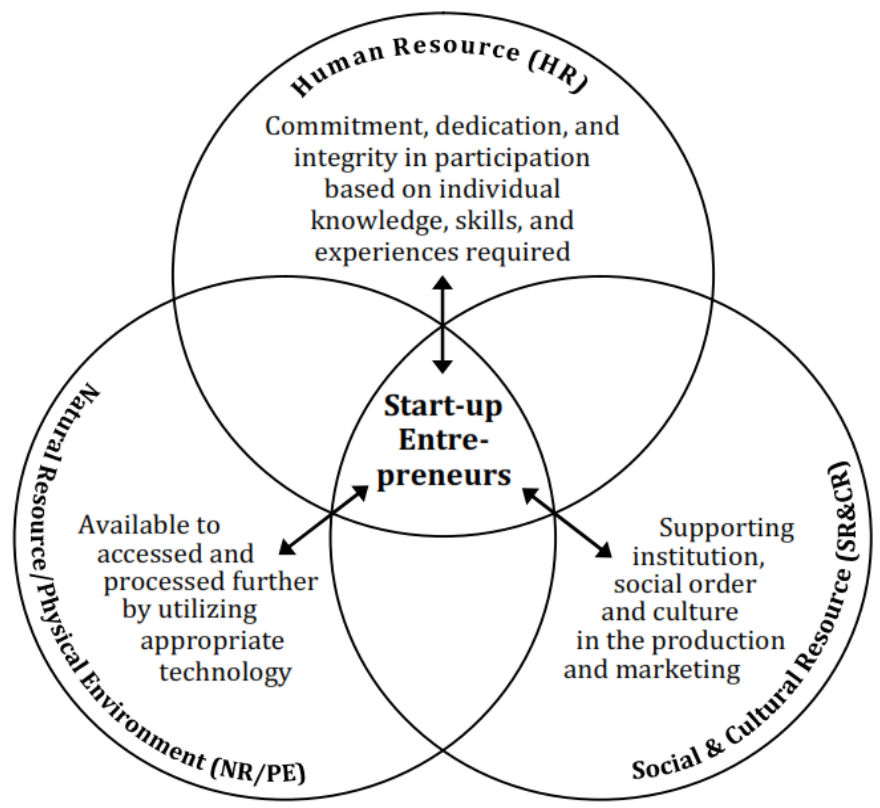

Figure 9: Synergistic collaborative in training for start-up entrepreneurs (Source: Witjaksono, 1998a: 8-10 \& 1998b: 12-13)

At the HR side, a person who wants to be a newly entrepreneur must have a set of knowledge, skills, and experiences required for starting-up a new business desired. At the same time he/she have to dedicate with highly commitment and integrity to sustain and develop his/herself as a real entrepreneur. At the NR/PE side, every person wants to be a newly entrepreneur must take a look first at the potencies of NR/PE surrounding his/her living site to be changed into a viable business unit through the utilization of appropriate technology, and at the same time, he/she ought to think and act how the business unit would create NR/PE better than before. At the SR/CR side, as a consequence of the first two sides, a newly entrepreneur must be a leader (pioneer) in changing the SR/CR conditions better than before.

Two other distinctions between GKD and P3T were: (i) the location of GKD already specified by local government, whereas the location of P3T depended upon where the participants came from, or currently reside; and (ii) the overall activities as well as outcomes of GKD just for the sake of empowering local and community economic development, whereas P3T just for the sake of empowering individual. 


\section{What makes KSM Sibermas claimed to be a miniature of Siparti 3-S?}

As aforementioned that the word "Sibermas" (Sinergi Pemberdayaan Masyarakat or Synergy of Community Empowerment) refers to synergy in empowering process and products resulted from synergistically efforts. Synergy in empowering process means that all activities is designed, executed, and controlled by all participants collaboratively. Products resulted from synergistically efforts means that whatever the result come out, it always be the effect of "how things work together", or the "science of synergy", or "synergistics", according to Joe Ravetz definition (Ravetz, 2013: 5102).

The science of synergy was actually--as shown from snapshots--applied by KSM Sibermas through a series of synergistically onsite-training. This synergistics was effective due to the underlying basic principles:

1. All training materials derived or obtained from resources available in the environment in which the activities carried out, i.e. waste materials available in every household daily and/or already pooled in the TPS RW-08.

2. The content of training materials (mostly technical know-how) were very easy to understand and practice to all participants.

3. All training participants voluntary engage into the cluster they choosed and willing to work collaboratively not only with other participants in the same cluster, but with participants from different cluster also.

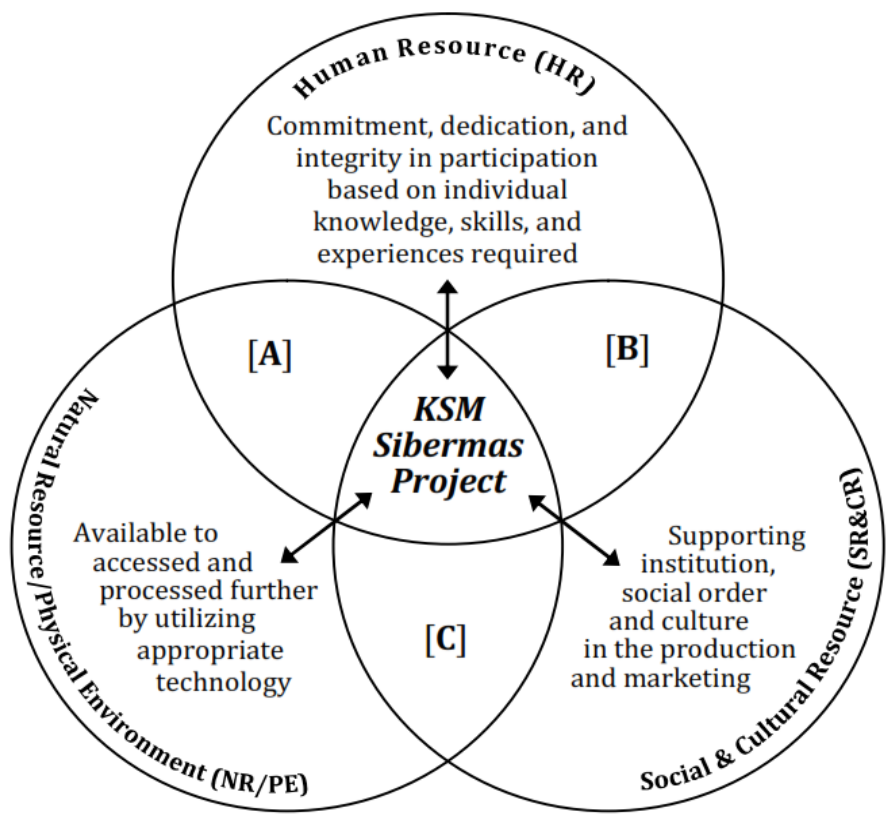

Figure 10: KSM Sibermas Project viewed as a miniature of Siparti-3S (Source: Slightly modified from Witjaksono, 2000: 7 \& 2001: 13)

The intersection represents:

A. Empowering HR to be able to utilization NR/PE through the appropriate technology.

B. Empowering HR to be able to build a socially \& culturally creative community.

C. Empowering SR\&CR to be able to build a sustainable and productive NR/PE.

The establishment of KSM Sibermas together with all dynamics aspects of training project reported here was the physical appearance and nature of how Siparti 3-S functioning well as it was defined in the previous articles (see Witjaksono, 2012: 1 \& 2014: 21). In other words, KSM Sibermas can also be defined as the physical appearance and nature of how Siparti 3-S 
functioning institutionally organized and managed properly in the context of empowering local community to reduce poverty.

\section{LESSONS LEARNED}

Although KSM Sibermas was actually an ad-hoc community group to operate only one term under the second phase of UPP1 (i.e. from March 2000 to June 2001), the author noted that there were at least three important lessons learned.

First, from the perspective of synergy theories, the ways how KSM Sibermas systematically manage three different clusters of training activity into a single system of delivery as depicted in Figures $1 \& 2$ is in accordance with the integrative definition of synergy offered by Benecke, Schurink \& Roodt (2007: 9): "Synergy is a concept that describes the systemic processes whereby business units of diverse, complex organizations will generate greater value through working as one system than working as separate entities." It should be noted here that the critical success of the systemic process through working as one system is not just as the cliché: "the whole is greater than the sum of its parts", but on the effects produced by the relationships among various forces, particles, elements, parts, or individuals in a given context - effects that are not otherwise possible (see Corning, 2003: 4). KSM Sibermas was successful in facilitating the diverse background of participants into a united movement and in rising collaborative performance through efficient and effective interaction (c.f. Meijers, 2007: 26).

Second, within the context of urban poverty reduction, the term "synergy" in Siparti 3-S was not only perceived as the combination of different resources those providing additional positive effect, or positive synergy (arithmetically expressed: $1+1>2$ ), but also perceived as what Andriy Andrushko (2012) called "reverse synergy" (arithmetically expressed: $4-2=3$ ), since the result 3 is getting an additional positive result 1, from the reduction of resource 4 with resource 2 . The later condition inclusively occurred during the practice of composting, recycling the paper, and making handicrafts. It means that while those processes reduce some amount of garbage volume in the TPS RW-08, at the same time there were three economical products obtained: compost pile, recycled papers, and handicrafts. Either positive synergy or reverse synergy, their occurrence during training process facilitated by KSM Sibermas was more or less closed to the second meaning below (quoted in Meijers, 2007: 26):

a) "Synergy means that when two or more actors co-operate, there is a positive result for both of them";

b) "synergy means that when co-operative behavior is implemented in order to exploit complementarity in the production of a particular good, advantages are obtained by economic actors taking place in a group";

c) "synergy means that when individuals or firms 'voluntarily and non-voluntarily' are part of a group, externalities may be present and exploited by these individuals or groups in conducting their economic activity". (Capello \& Rietveld, 1998: 64).

Third, from the perspective of community participation, what had been done and outcomes achieved through KSM Sibermas Training Project seems resemblance to Lasker \& Weiss (2003: 122-123) argument:

Synergy is a key indicator of a successful collaborative process because it reflects the extent to which a partnership can accomplish more than any of its individual participants and become a whole that is greater than the sum of its parts. A partnership creates synergy by combining the complementary knowledge, skills, and resources of different people and organizations. When a partnership achieves a high level of synergy, the group as a whole has an advantage over its individual participants in solving 
complex problems, is able to think in new and better ways about the problems it is trying to address, take more comprehensive actions to address those problems, and develop a stronger and more supportive relationships with the broader community. ..... Only by combining the knowledge, skills, and resources of a broad array of people and organizations can communities understand the underlying nature of such problems or develop effective and locally feasible solutions to address them.

\section{References}

Andrushko, A. (2012). The Reverse Synergy: Another Way of Thinking, International Journal of Economic Practices and Theories, 2(2): 68-74.

Benecke, G., Schurink, W. \& Roodt, G. (2007). Towards a Substantive Theory of Synergy, SA Journal of Human Resource Management, 5(2): 9-19.

BKM Tlogomas. http://www.bkmtlogomas.com/profil.

Capello, R. and P. Rietveld (1998) “The Concept of Network Synergies in Economic Theory: Policy Implication.” In: K. Button, P. Nijkamp and H. Priemus (Eds.) Transport Networks in Europe, pp. 57-83. Cheltenham/Northampton: Edward Elgar.

Corning, P. (2003). Nature's Magic: Synergy in Evolution and the Fate of Humankind. Cambridge: Cambridge University Press.

Dharmawan, A. (1999). Bahan Pelatihan Pembuatan Kompos (Training Materials for Composting). Malang: LPM Universitas Negeri Malang.

Jawa Pos - Radar Malang, 24 April 2000. "Sampah di Malang Bisa Diatasi” (Garbage in Malang Can be Overcome). Jawa Pos - Radar Malang, 12 May 2000. "Masalah Sampah Bukan Tanggungjawab Pemda” (The Garbage Problem Is Not the Responsibililty of Local Government).

Jawa Pos - Radar Malang, 12 May 2000. “Kompos Media Utama Negara Maju” (Compost is the Prime Media Gardening in Developed Countries).

Jawa Pos - Radar Malang, 12 May 2000. “Kompos Solusi Termurah Mengatasi Sampah - Tanpa Menunggu Pemda Bisa Ditangani Sendiri" (Compost Is the Cheapest Solution to Overcome Garbage - Without Waiting for the Local Government can be Handled by Ourselves).

Jawa Pos - Radar Malang, 16 June 2000. "Sampah Belum Bisa Diatasi" (Garbage Is Not Solved Yet).

Jawa Pos - Radar Malang, 24 June 2000. "Sampah di Malang 1,168 Juta Meter Kubik" (1.168 Million m3 Garbage in Malang).

Kustiawan, U. (1999). Bahan Pelatihan Pembuatan Daurulang \& Kerajinan Kertas (Training Materials for Recycling \& Crafting Paper Waste). Malang: LPM Universitas Negeri Malang.

Kuswidiati, W. (2008). A Case Study of Participatory Development in the One Village One Product Movement: Green Tourism in Ajimu Town, Oita, Japan and Agro Tourism in Pasuruan, East Java, Indonesia. International OVOP Policy Association Journal 10(11), 122-130.

Lasker, R.D. \& Weiss, E.S. (2003). Creating Partnership Synergy: The Crtitical Role of Community Stakeholders, JHHSA, summer 2003, pp. 119-139.

Meijers, E.J. (2007). “Synergy in Polycentric Urban Regions: Complementarity, Organising Capacity, and Critical Mass." Dissertation. Delft University of Technology, Delft, the Netherlands.

Ravetz, J. (2013). New Futures for Older Ports: Synergistic Development in a Global Urban System, Sustainability, 5: 5100-5118.

Savitri, D. (2008). Sustainable Development of Rural Revitalization: The Pioneer of OVOP Movement. International OVOP Policy Association Journal, 10(7): 79-88.

Stenning, N. \& Koichi, M. (2008). Knowledge and Networking Strategies for Community Capacity Development in Oyama-machi: An Archetype of the OVOP Movement. International OVOP Policy Association Journal, 10(6): 67-78. 
Witjaksono, Mit (1997). Siparti 3-S untuk Pemberdayaan Gerakan Kembali Ke Desa (GKD) Propinsi Jawa Timur (Siparti-3S for Empowering the 'Back-to-Village Movement' in East Java Province). Proposal Submitted to the Board of Regional Development of East Java Province.

Witjaksono, Mit (1998a). "Siparti 3-S \& ETOP untuk Wirausaha Baru” (Siparti-3S \& ETOP for the Start-up Entrepreneurs). YBUM: Malang.

Witjaksono, Mit (1998b). “Laporan Akhir Kegiatan P3T - Paket WUB \& LEP.” (Final Report of P3T Project - WUB \& LEP Packages). YBUM: Malang.

Witjaksono, Mit (2000). Proposal Pelatihan: Pengolahan Limbah untuk Pembuatan Aneka Produk Ekonomis dan Berwawasan Lingkungan (Project Proposal: Handling Waste Materials Training to Create Economically and Environmental-Friendly Products). KSM “Sibermas”, BKM Kelurahan Tlogomas, Kecamatan Lowokwaru, Kota Malang.

Witjaksono, Mit (2001). Laporan Akhir: Proyek Pelatihan Pengolahan Limbah untuk Pembuatan Aneka Produk Ekonomis yang Berwawasan Lingkungan (Final Report: Training Project Handling Waste Materials and Making Economically and Environmental-Friendly Products). KSM "Sibermas", BKM Kelurahan Tlogomas, Kecamatan Lowokwaru, Kota Malang.

Witjaksono, Mit (2012). Siparti 3-S, Triple Helix, dan Modal Sosial dalam Penguatan IKM (Siparti 3-S, Triple Helix, and Social Capital in Strengthening Small Industries)." Paper presented at the National Seminar on "Optimisme Ekonomi Indonesia 2013, antara Tantangan dan Peluang" (Optimism of Indonesia Economy 2013, between Challenges and Opportunities). Open University, Jakarta, December 12, 2012.

Witjaksono, Mit (2014). Siparti 3-S, Triple Helix, and Social Capital in Strengthening Local Competitive Industries in Indonesia, Journal of Economics and Sustainable Development, 5(3): 21-35.

World Bank PAD (1999). Project Appraisal Document: Indonesia Urban Poverty Project, Urban Development Sector Unit, Indonesia Country Department, East Asia and Pacific Region. Jakarta: World Bank.

World Bank PAD (2002). Project Appraisal Document: Indonesia Urban Poverty Project, Urban Development Sector Unit, Indonesia Country Department, East Asia and Pacific Region. Jakarta: World Bank. 